\title{
小児両側同時性ベル麻㿁の一例
}

\author{
村上 匡孝・中江進

\section{Bilateral Simultaneous Bell's Palsy in a Child}

\author{
Masataka Murakami and Susumu Nakae \\ (Matsushita Memorial Hospital)
}

A 12-year-old boy developed simultaneous bilateral facial paralysis following rhinopharyngitis. There was no evidence of systemic disease. Therefore, the diagnosis of bilateral simultaneous Bell's palsy was made. After about 2 weeks of conservative treatment he showed complete recovery. Rises in antibody titers to herpes simplex virus and rubella virus, and a rise in EB-VGAIgG were demonstrated. Psychological tests showed a personality similar to that found in psychological hearing loss. So this palsy seemed to be due to viral infection plus psychological factors.

Key words: Bell's palsy, bilateral simultaneous, facial palsy, child, psychological test

\section{はじめに}

両側同時性顔画神経麻痺は比較的稀な聅患で ある。今回我々は，12才男児に発症した両側同 時性ベル麻痺の 1 症例を経験したので若干の文 献的考察を加えて報告する.

\section{症例 \\ 症例 : 12才 男}

主訴：仮面様顔貌

既往歴：特記すべきととなし

現病歴：昭和62年 3 月 10 日発熱，4 日間感冒 症状が続いた。 3 月20日，表情がそしくなった ことに母親が気付く。しだいに食事が両口角よ り流出しやすくなり, 閉眼むできないため, 当 院小児科を受診し小児神経症を疑われ，神経学 的検索や心理テスト等の検査の後, 当科に照会 となった。

初診時現症と検查所見：両側顔西筋遇動の不 全麻箄を認め仮面様顔貌である（図 1 ）。スコ
アは両側13点で左右差はなく味覚低下屯認めな い. 脳神経を含め他の神経症状は認めない. 耳 下腺部触診，鼓膜所見に異常なし，標準純音聴 力検査結果は正常範囲で，ティンパノグラムは A型，アブミ骨筋反射は両耳ともに同側耳刺 激, 反対耳刺激と屯反応良好であった。

隐休経過と検査結果（図 2 ）：ステロイド剤 (プレドニソロン $15 \mathrm{mg} /$ 日より漸減), ビタミン B 群， A T P等を用いて治療を開始する一方, 他病変の検索を計画した. まず経過について は, 顔面筋運動は右加ら改善し始め（図 $3 \mathrm{~A}$ ), 初診 1 週後の筋電図では左右ともに脱神経所見 を認めず， 2 週後にはスコアも右 39 点, 左 35 点 と回復し, 左眼周囲に筋力低下のみ残存してい る（図 3 B). 4 週後には左右とも40点まで改 善し, その後林瘏の再発や他の神経症状の出現 はみていない。諸検查の結果については, 頸部 C Tでは頭蓋内，側頭骨内，耳下腺部ともに異 
常を認めなかった，胸部 X線，血液・尿検査結 果にも異常を認めず，脳波の異常もなく小児科
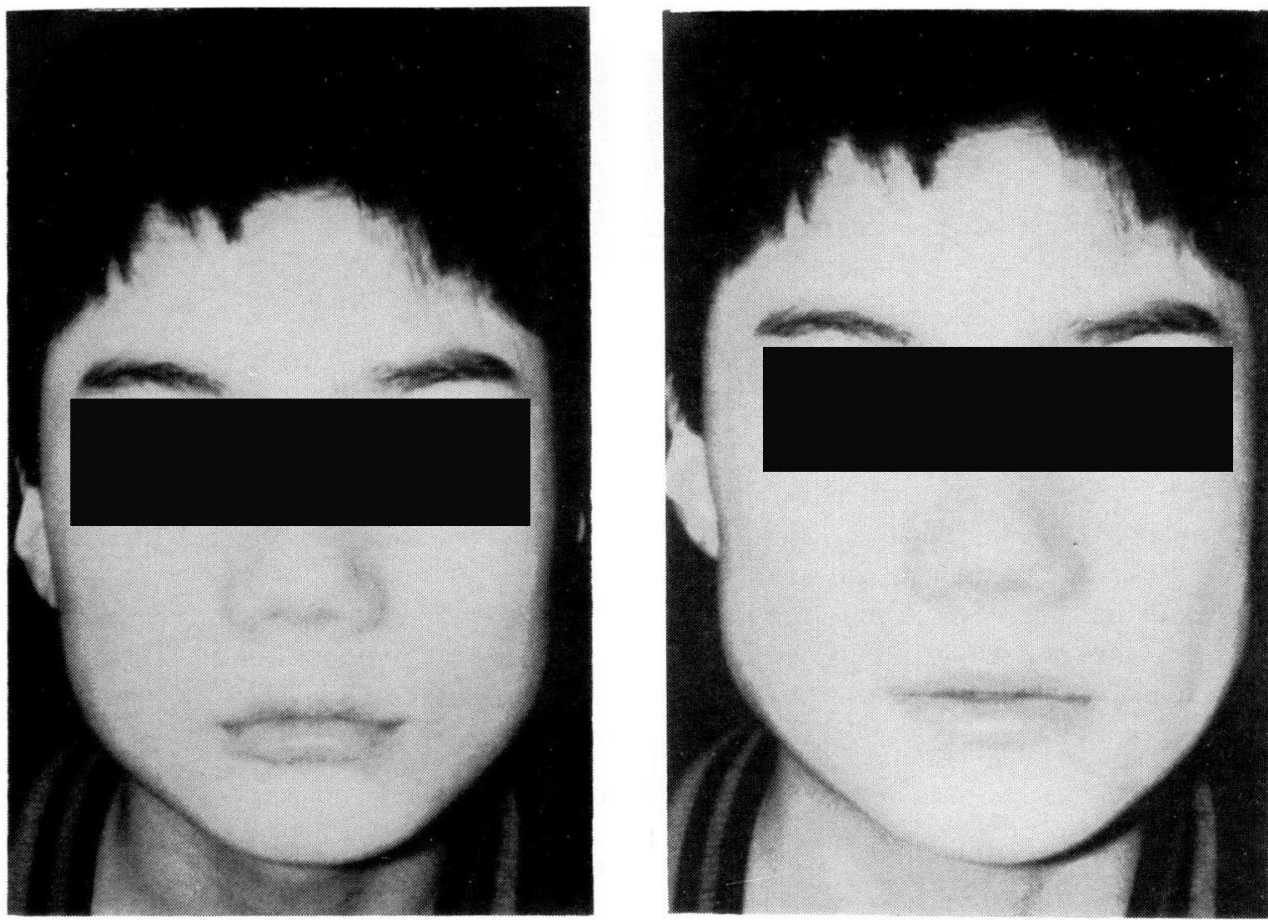

図 I 初部時の顔貌（麻瘦発症12日目）

左：強く閉眼させて口とがらし，右：強く閉眼させて「イー」と菌をみせる.

閉眼できず，口輪筋の動きもない仮面樣顔貌である．スコアは両側とも13点である.

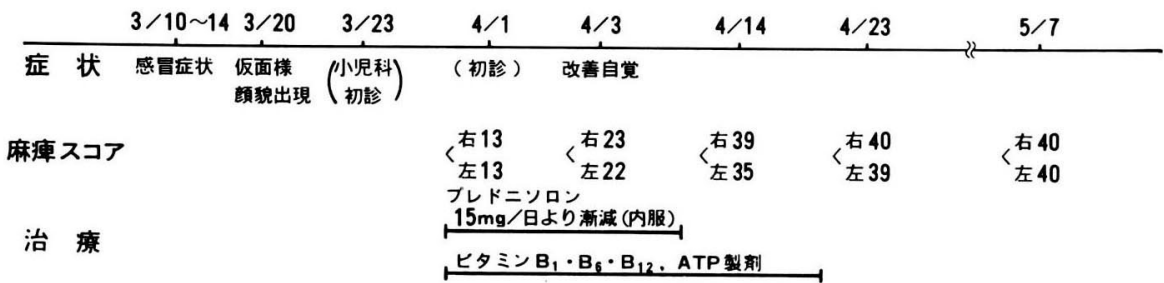

検 查

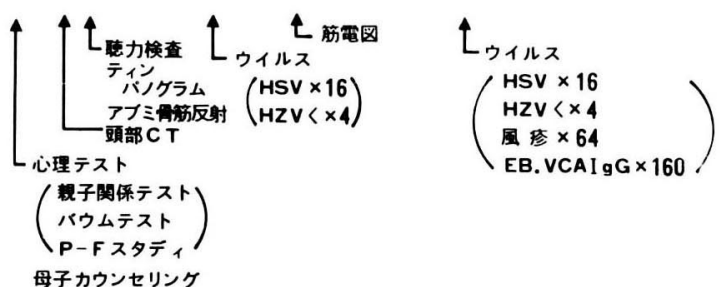

図 2 臨床経過 

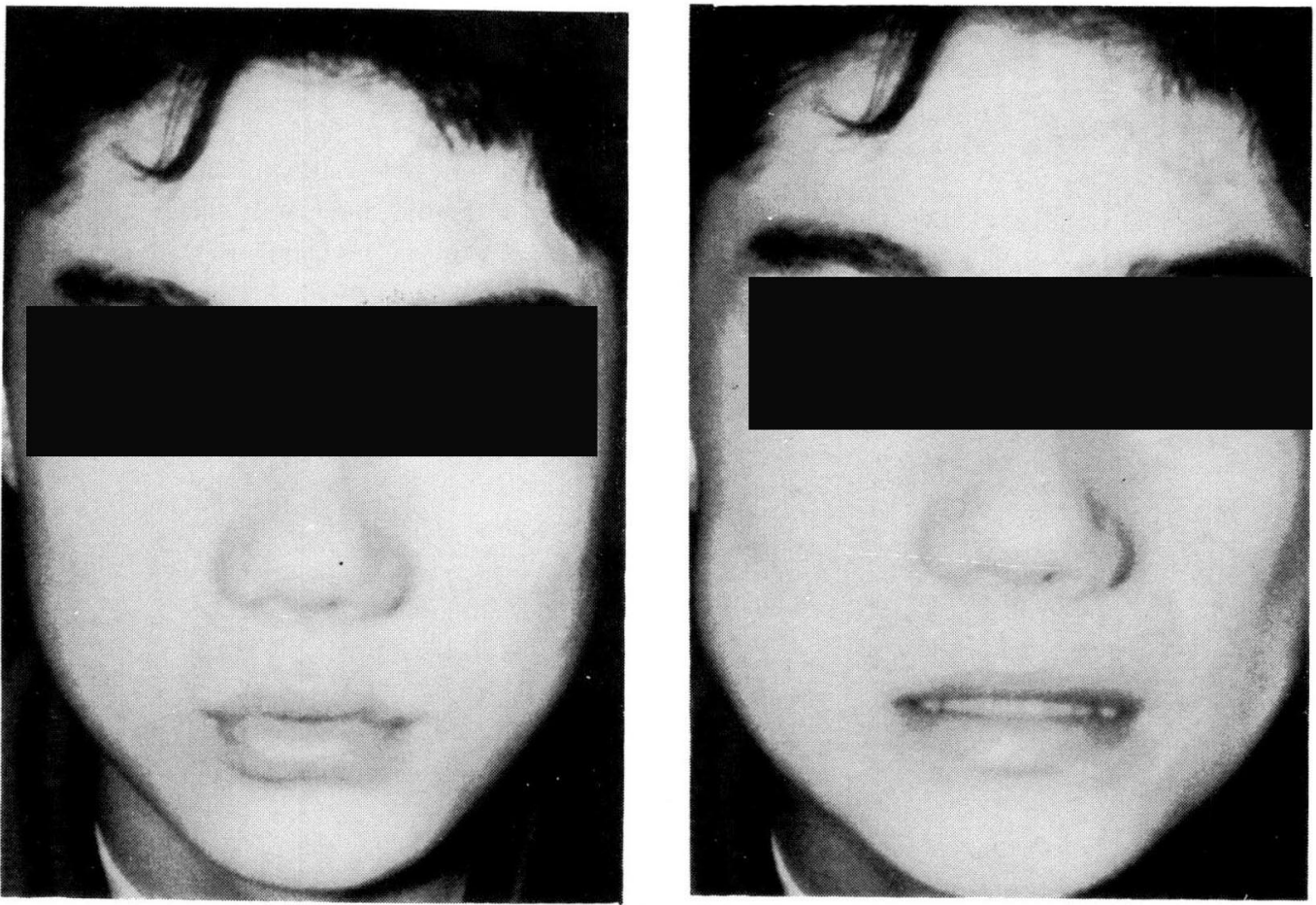

图 3 A 治療 3 日後 (麻瘏発症 15 日目)

左：強く閉眼させて口とがらし, 右：強く閉眼させて「イー」と画をみせる.

口輪筋の動きが出てきている. 閉眼は右の方が回復が早い. スコアは右 25 点, 左 23 点.
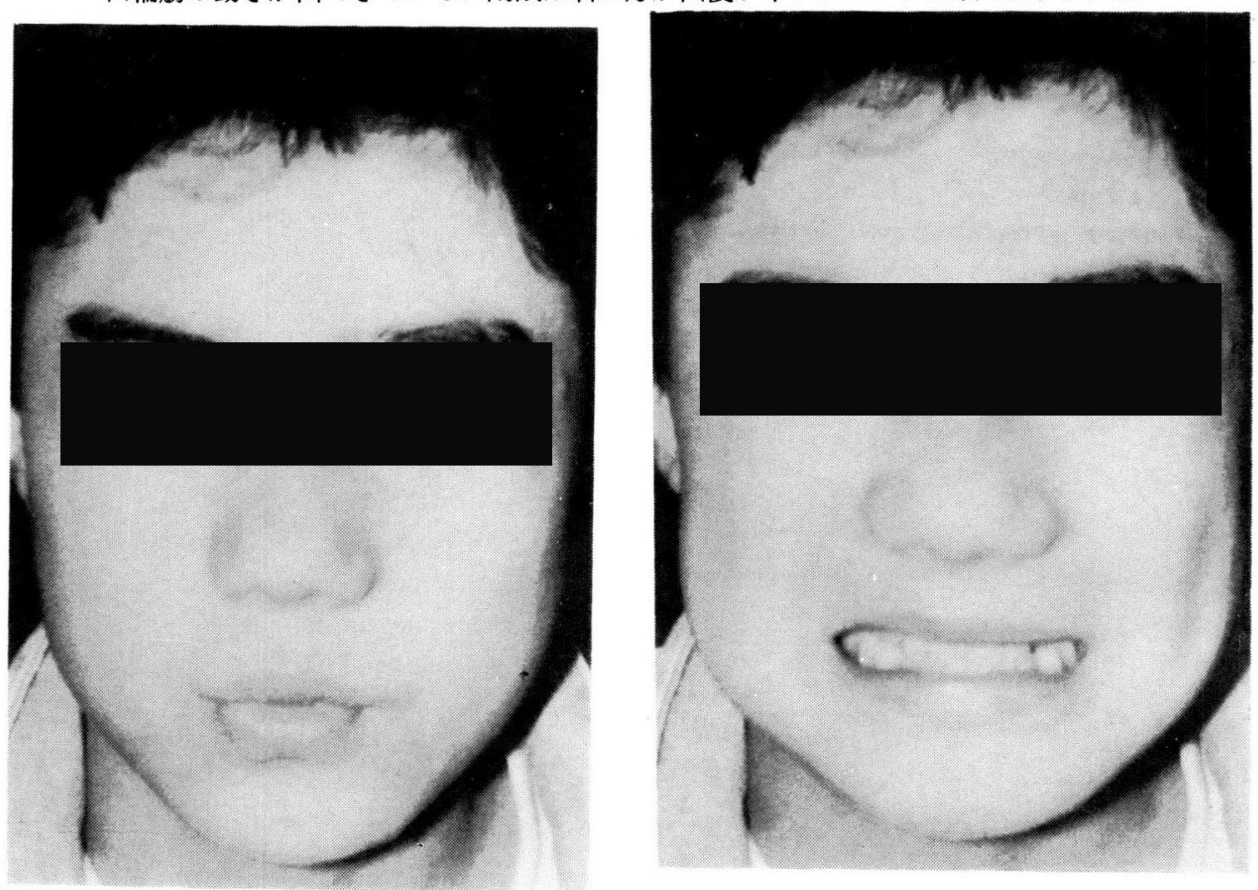

図 3 B 治療14日後（麻猠発症26日目）

左：強く閉眼させて口とがらし，右：強く閉眼させて「イー」と雨をみせる. スコア右顔面39点, 左顔面35点まで回復. 
価が単純ヘルペス16倍，風掺64倍，EB-VCA

IgG が160倍と上昇していた。松下健康管理セ ンター小児保健部で行われた心理テストの結果 を付記する。

田研式親子関係診断検查では，両親の「溺愛 型」，父親の「積極的拒否」，母親の「干涉」と 「不安」の項目が危険地倠に近く，患児につい ては「反社会性」について親への反抗や妹をい じめることなど，「非社会性」について対人関 係的に引っ达み思案倾向，「興味・意志」につ いて日律性や根気の火如，「学力・能力」につ いて学業不振之学湔嫌偲感が強く認められた。

バウムテストでは，患児の现実生活への防衛 的態度，压迫された感情，反抗的感情，安全へ の欲求がある半而，不完全な発達，決断力の欠 如と不安定で感じやすい抑圧された感情倾向が 伺われるという。

絵画欲求不満（P-Fスタディ）テストで は，適合性は普通であるが，社会的に必要な人 や物に対する攻撃性が低く欲求不満に基づく不 平や不満を抑えて表出しない倾向，原因に対す

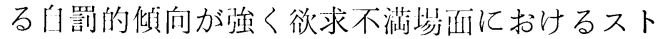
レスをうまく解決処理できないてとが何わ机る という.

\section{考察}

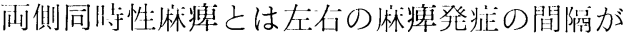
1 週間以内のもの ${ }^{1)}$ といわれているが，我々の 症例は両側林䡟の同日発症なので完全同時性嫲 瘏として差支えないと思われる。中村ら"1 の統 計によると顔而神経麻脾症例の丩で両側顔面神! 経林瘏は $2.3 \%$ にすぎないが両側同時性ベル嫲

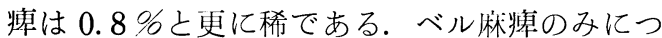
いてみると，柳原" ${ }^{2)}$ は両側同時性ベル麻痺はべ ル林瘏2414例中22例，1\%であると述べ，太田 ら ${ }^{3)}$ の施設でも両側同㭙性ベル林瘏は全ベル炑 痺中の $0.4 \%$ とされ，両側完全同時性ベル恘痺 となると極めて稀と考えられる。

一力，両倒性顔面神経休痺の原因は，小林 ら")によると表 1 の如く種々のものが举げら れ，本邦の文献報告では全身的系統疗患では
表 I 両側性顔面麻㿁の原因（小林）

\section{I . Congenital}

1. Moebius syndrome

2. Thalidomide-embryopathy

3. Congenital absence of facial musculature

4. Hypoplasia of facial nerve nucleus

II . Infectious

A. Central

1. Meningitis : bacterial fungal

2. Encephalitis

3. Basilar arachnoiditis

4. Toxoplasmosis

5. Polio

6. Infectious mononucleosis

7. Malaria

8. Syphilis

9. Tetanus

B. Peripheral

1. Otitis

2. Mumps

3. Herpes zoster

4. Leprosy

5. Diphtheria

III. Neoplastic

1. Pontine angle tumor

2. Leukemia

IV. Traumatic

V. Metabolic

1. Diabetes mellitus

2. Alcoholic neuropathy

3. Porphyrinuric neuropathy

4. Hypercalcemia

5. Myasthenia gravis

VI. Non-inflammatory

1. Vascular causes

2. Multiple sclerosis

3. Bulbar palsy

4. Amyotrophic lateral sclerosis

VII. Association with miscellaneous diseases

1. Periarteritis nodosa

2. Sarcoidosis : Heerfordt syndrome

3. Landry-Guillain-Barre' syndrome

4. Melkersson-Rosenthal syndrome

VIII. Psychiatric disease

IX. Idiopathic

1. Bilateral Bell's palsy

2. Recurrent and alternating facial palsy 
Guillain-Barre 症候群を含めた多発性神経炎 や Heerfordt 症候群を含めた Sarcoidosis が多い5). したがって, 全身的系統疾患を常に 考慮し, 単なる特発性麻瘏之即断し全身検索が 不充分にならないように，また，治療が遅れ女 ように注意が必要である. 我々の症例では完全 同時性顔面麻㯅のみで, 他の随伴症状を認め ず, 胸部X線, 血液血清検查所見, 側頭骨 - 耳 下腺部諸検査にあ異常は認めなかった。また， 神経学的に他に異常を認めないととからべル 麻瘦之考元た，我々の症例では，治療後 7 日 目 (発症20日後) で筋電図は両側と屯に低振幅 パターンのみであり 2 週後にはほぼ回復してい る. 両側同時性ベル麻痺の過去の報告（表 2 ） をみると小児での症例は珍しいといえるが，ほ とんどが予後は良好である.

次にての症例の病態について考察するが，柳 原 ${ }^{2)}$ のまとめた誘因の中でも感冒之精神的瘦労 が注目され，それぞれウイルス感染と心因性要 因に関係する，まずウイルス感染であるが，検 索した中では単純へルペス, EB-VCA IgG の 抗体価の上舁を認める。ペア血清の詳練な検索 が不充分であるので推定であるが，ヘルペスウ イルス群とベル麻舫発症との検討6) によると,

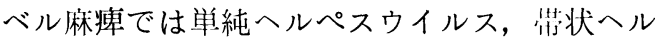

ペスウイルス，EBウイルス初感染でなく再活 性化である可能性が示されている，心因性要因 については，心理テストの結果が興味深く，患 児の性格が内向的で感受性が強く, 欲求不満場 面や対人関係で自己主張するととなく受容的に 我慢する傾向があること，また，保護的な家庭 環境の中で親に対して依存的だが内面には大き なエネルギーを有し抑圧され動摇する精神面が あるととは，我々の経験での心因性難聴患者に 多い性格傾向7)である.さらに，小学校から中 学校に移り環境が変化する時期に発症している

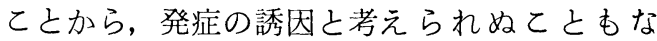
い. 高年齢初産に対する不安や先に発症した側 の顔面神経麻痺に対する不安などの神経的スト レスが示唆される妊娠末期の両側ベル麻痺症例 の報告 ${ }^{81}$ あある. しかし，両側発症の誘因を心 因とするには難があり今後の検討を要する，む しろ, 両側発症については, その両側の顔面神 経の易傷害性の差によって一側性ベル林痷，両 側同時性ベル麻痺像を呈し，一側性ベル麻痺の 中に潜在性両側ベル麻瘏が存在するという解釈 5) があり，我々の症例ではウイルス感染による 林痺像を呈するほどの傷害が両側に生じたと考 えたい，

また，両側顔面神経麻癘による能面様の特異

表 2 両側同時性ベル麻痻症例（間隔 1 週間以内）

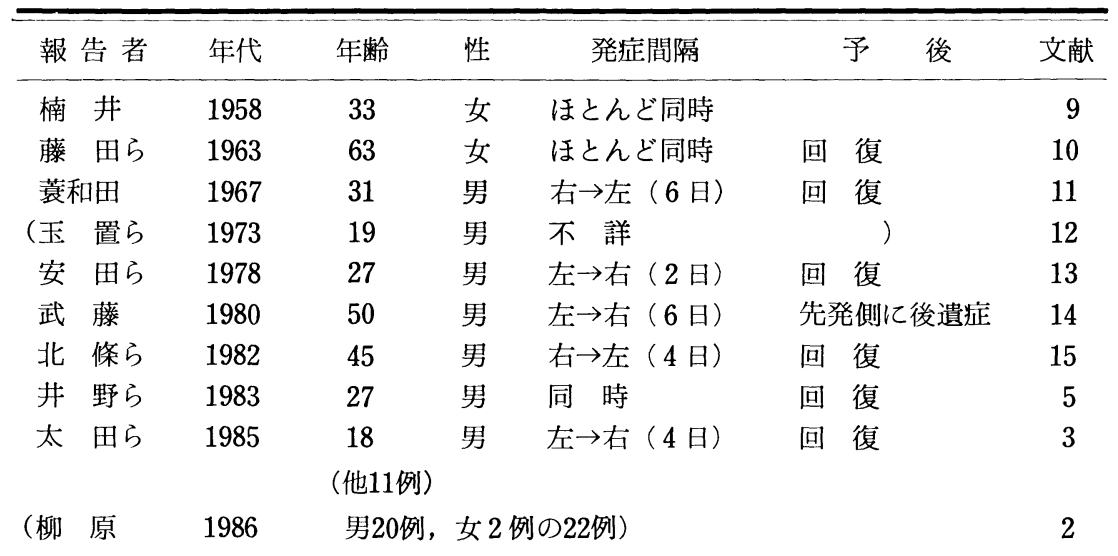

村上

1987

12

男同 時

回 復 
顔貌に加えて患児が本来無口であったために， 枝初に患児を診察した小児科医が神経症を疑っ て精神神経科に綠介した。そのため性格倾向ま

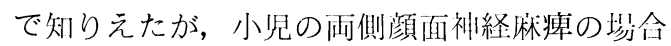
は認識が少ないと精神疾患とみなされるととが あり注意が必装であると感じた。

\section{まとめ}

感莦症状後に発症し保存的加療で早期回後し た12才男子の闭侧同将性バル林脾症例を報告し た. 単純ヘルペス, EBVCA IgGの抗体価が 上算しウイルス感染が鿌目の吅能性がある. 小 学校から中学校に移る発症将期と心理テストで

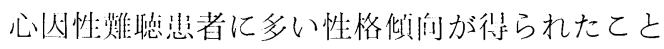
から本症例では唀因の一つに心理而间影㹣があ ると思われた。

尚, 本論文の要旨は第 222 回日耳崖大阪㤼方連合会 で口演した。

\section{文献}

1) 小村光士蚛, 松本山沓, 他: 両侧性および反復性 顔面神経麻稗の統計的観察一その 1 原因につい て. 耳鼻臨床 $73: 1673 \sim 1678,1980$.

2 ) 柳原尚明: ベル麻䠋の臨床. 側頭骨内顔面神経麻 痺. 病態と治療 (柳原尚明). $20 \sim 27$ 頁, 愛瑗大 学医学部耳鼻咽喉科学教室, 愛媛, 1986.

3 ) 太田宗一郎, 若杉文吉: 両侧同時性顔面神経麻 瘦. Facial N Res JPN $5: 221 \sim 223,1985$.

4) 小林武夫, 新美成二, 他：両側性顔面神経麻獀に
ついて. 耳喉 $46: 17 \sim 23,1974$.

5 ) 井野千代徳, 花岡真子, 他：雨側完全同時性ベル 麻㾝の 1 症例. 耳㬋 $55: 1023 \sim 1026,1983$.

6) 柳原尚明：ベル森瘏におけるウイルス感染. 側頭 骨内顔面神経麻瘏病態と治療 (柳原尚明)。59 82頁, 愛媛大学医学部耳鼻咽喉科学教室, 愛媛, 1986.

7 ）村上匡孝, 中江，進：当科で経験した心因性難聴 の 5 症例. 松仁会医誌 $25: 45 \sim 53,1986$.

8 ）上出一朗, 尔野原邦生, 他: 両側后時性顔面神経 麻辉の 4 为:例．耳喉 $55: 921 \sim 928,1983$.

9) 楠井賢造: 末梢性軕側顔面神経麻淿. 臨床之研究 $35: 1543 \sim 1546,1958$.

10）滕田秀三，他：両側性顔面神経麻淿の 1 例。㕕血 医学 16:564〜565, 1963.

11）筫和田宽子：両側性顔面神経麻焷の 4 例. 耳舆臨 床 $60: 525 \sim 532,1967$.

12）玉䈯弘光，他：両側顔面神経麻脾狂: 例. 日耳舅 $76: 921 \sim 928,1973$.

13）安田宏一, 池田雄祐, 他：雨側同時性ベル林焷の 1例. 耳茾 $24: 370 \sim 375,1978$.

14）武藤次郎：両側同時性顔面神経麻焒!の 2 証例. H 㗹 $53: 93 \sim 98,1981$.

15）北条和博，他：両側性顔面神経麻将!の 2 炡例. 开 畚臨床 $75: 1037 \sim 1045,1982$.

原稿採択：昭和 62 年 12 月 5 日

別刷請求先：村上匡孝

T602 京都市上京区河原町広小路上儿梶井町 465 京都府立医科大学耳鼻咽喉科学教室 